\author{
Climate Change Ethics and the Non-Human World \\ Brian G. Henning \& Zack Walsh, eds. Routledge, 2020. Pages 196-210
}

\title{
14 Wonderland Earth in the Anthropocene epoch
}

\author{
Holmes Rolston III
}

Wonders are many, and none is more wonderful than man.

- Sophocles, Antigone

\section{Wonderland planet}

Earth is, by all accounts, a wonderland planet. Let's take that first from rocket science. Viewing Earth from space, the astronaut Michael Collins recalled being earthstruck: "Earth is to be treasured and nurtured, something precious that must endure" (Collins 1980, 6). No one contests that: scientists, philosophers, politicians, economists, theologians, business executives, farmers, housewives, ordinary people. Whole Earth photographs from space are as widely viewed as any in human history and, in pensive moments, invariably give viewers pause to wonder at their stunning home planet.

In the cosmos, remarkable features produce billions of galaxies, with stars generating elements suitable for forming planets. Life is so far known only on planet Earth, where over billions of years, there has been an explosion of life, moving through several billion species, reaching humans in an evolutionary process. By widespread scientific accounts, humans result from a cosmic "anthropic" principle.

In the last half century, scientists have found dramatic interrelationships between astronomical and atomic scales that connect to make the universe "userfriendly." Astronomical phenomena, such as the formation of galaxies, stars, and planets, depend critically on the microphysical phenomena. In turn, those midrange scales, where the known complexity mostly lies, depend on the interacting microscopic and astronomical ranges. The stars are the furnaces in which all but the very lightest elements are forged. The stars run their courses, and many explode as supernovae to disperse their matter throughout space. Such matter is condensed as planets, and life evolves out of such elements.

If the scale of the universe were much reduced, there would not have been enough time for elements to form. If the expansion rate of the universe had been a little faster or slower, then the universe would already have recollapsed or the galaxies 
and stars would not have formed. How fast the universe is expanding depends on the value of what physicists call the "cosmological constant." They symbolize this with the Greek letter $\lambda$. This constant is quite small, nearly zero but not zero. Martin Rees, leading British astronomer at Cambridge University, reflects,

Fortunately for us (and very surprisingly to theorists) $\lambda$ is very small. Otherwise its effect would have stopped galaxies and stars from forming and cosmic evolution would have been stifled before it could even begin. . . The cosmic number $\lambda$-describing the weakest force in nature, as well as the most mysterious - seems to control the universe's expansion and its eventual fate.

(Rees 2000, 3, 98-99)

John Barrow, physicist and mathematician at Cambridge, looks out at the universe: "Many of its most striking features - its vast size and huge age, the loneliness and darkness of space - are all necessary conditions for there to be intelligent observers like ourselves" (Barrow 2002, 113).

Four fundamental forces hold the world together: the strong nuclear force, the weak force, electromagnetism, gravitation. Change slightly the strengths of any of those four forces, change critical particle masses and charges, and the stars would burn too quickly or too slowly, or atoms and molecules (including water, carbon, and oxygen) or amino acids (building blocks of life) would not form or remain stable. We have discovered that what seem to be widely varied facts really cannot vary widely, indeed, that many of them can hardly vary at all, and have the universe develop the matter, life, and mind it has generated. Roger Penrose, physicist and mathematician at Oxford, is impressed by "the extraordinary degree of precision or 'fine-tuning' for a big bang of the nature that we appear to observe." $\mathrm{He}$ concludes that ours is "an extraordinarily special Big Bang" (Penrose 2005, 726, 762). That big bang is now thought to have been an explosion resulting from a fluctuation in a quantum vacuum.

Paul Davies, a cosmologist formerly at Cambridge, now at the Arizona State University, claims that we hit "the cosmic jackpot," a universe "just right for life" (Davies 2007). Max Tegmark, cosmologist at MIT, phrases this more technically: "virtually no physical parameters can be changed by large amounts without causing radical qualitative changes to the physical world. In other words, the 'island' in parameter space that supports human life appears to be quite small" (Tegmark 1998, 6).

Where once there were no species on Earth, there are today five to ten million. Prokaryotes dominated the living world more than three billion years ago; there later appeared eukaryotes, with their well-organized nucleus and cytoplasmic organelles. Single-celled eukaryotes evolved into multi-celled plants and animals with highly specialized organ systems. First, there were cold-blooded animals at the mercy of climate and later warm-blooded animals with more energetic metabolisms. From small brains emerge large central nervous systems. Although 
biologists contimue to debate "progress" in natural history, we need to put some kind of an arrow on evolutionary time.

The life story is different, because in biology, unlike physics, chemistry, geomorphology, or astronomy, something can be learned. Genes are cybernetic units of inheritance, capable of discovering and storing life information and elaborating it. Such functional agency is a novel wonder on Earth. The novelty is that matter-energy enters into information states. With its genetic coding, an organism is "informed" about how to make a way through the world, how to cope in its niche. Past achievements are recapitulated in the present, with variations; these results get tested today and then folded into the future. Random mutation figures into a larger generative process; species generate and test new possibilities. The challenge is to get as much versatility coupled with as much stability as is possible. This requires optimizing twin maxima, keeping past knowledge while exploring the nearby search space for better adaptation.

Organisms compete, struggling to hold a place against other lives. To be alive is to have problems. Survival is the name of the game. Yet in a more inclusive perspective, the idea of adapted fit also requires a niche, a place to be, and includes a life support system. An ecology is a home. The currents of life flow in the interplay of environmental conductance and environmental resistance. An environment that was entirely hostile would slay all; life could never have appeared within it. An environment that was entirely irenic would stagnate life. The vital natural process is of conflict and resolution. The organism is tested for how much information it can contribute to the next generation. Survival of the fittest turns out to be survival of the senders.

The strange wonder now is that the cosmic start-up seems a setup for life, necessary but not sufficient. Yet such life is rare in the universe and exploding on Earth. Life starts up and then smarts up. Scientists have found other planets, currently over a thousand of them. But those on which life seems possible (in the range of liquid water and adequate energy) are rare among them. Wonderland Earth is necessary and sufficient for life. "It appears that Earth got it just right," concluded Peter D. Ward and Donald Brownlee, a geologist and an astronomer, celebrating "Rare Earth" and noting why complex life will be rare in the universe (Ward and Brownlee 2000, 265). Lewis Thomas, a famous biologist, celebrates how Earth is "the only exuberant thing in this part of the cosmos" (Thomas 1975, 145). A good planet is hard to find.

\section{Humans - the wonder of wonders}

On Earth, humans are, by all accounts, the most complex and startling species. Humans are endowed with a genetic heritage producing the human mind, by far the most complex thing known, of virtually infinite complexity, capable of semantic and symbolic speech. With such mind, they generate cumulative transmissible cultures, elaborating high orders of rational and emotional thought in science, philosophy, ethics, and religious faith. Humans alone ask who they are, where they are, and what they ought to do. That humans evolved out of fossil 
stardust, creatively generated out of a fluctuation in a quantum vacuum, is quite a miracle.

The explosive growth of the human brain, sponsoring the cognitively spectacular human mind is the principal wonder on Earth. Edward O. Wilson, Harvard University, remarks, "No organ in the history of life has grown faster" (Wilson 1978, 87). Steve Dorus and his team of neurogeneticists, University of Chicago, conclude, "Human evolution is characterized by a dramatic increase in brain size and complexity" (Dorus et al. 2004, 1027). J. Craig Venter and over 200 co-author geneticists call the human brain "a massive singularity" (Venter et al. 2001, 1347).

Michael Gazzaniga, prominent neuroscientist, University of California, Santa Barbara, speaks of "the explosion in human brain size":

We are hugely different. While most of our genes and brain architecture are held in common with animals, there are always differences to be found. And while we can use lathes to mill fine jewelry, and chimps can use stones to crack open nuts, the differences are light years apart... We humans are special.

(Gazzaniga 2008, 1-3, 13)

The human brain is not just a scaled-up version of a chimpanzee brain. Humans are remarkable in their capacities to process thoughts, ideas, and symbolic abstractions figured into interpretive gestalts with which the world is understood and life is oriented. This higher consciousness is a constitutive dimension of humans and is absent in all other species. The key threshold is the capacity to pass ideas from mind to mind. There is no clear evidence that chimpanzees attribute mental states to others.

Chimps have little or no "theory of mind"; they do not know other minds are there with whom they might communicate, to learn what they know. Or, if you prefer to say that one chimp can know what another knows, chimps have a theory of immediate mind (one chimp sees that another chimp knows where those bananas are); humans have a theory of the ideational mind (one human teaches another the Pythagorean theorem). Humans have ideational uniqueness. Their cultural transmission makes it possible for an individual to inherit the discoveries of thousands of others before him, discoveries that the individual could not make in a single lifetime.

Although chimpanzees collaborate to hunt or get food, Michael Tomasello and his colleagues at the Max Planck Institute for Evolutionary Anthropology, Leipzig, conclude,

It may be said with confidence that chimpanzees do not engage in collaborative learning. ... They do not conceive of others as reflective agents - they do not mentally simulate the perspective of another person or chimpanzee simulating their perspective... . There is no known evidence that chimpanzees, whatever their background and training, are capable of thinking of other interactants reflectively.

(Tomasello et al. 1993, 504-5) 
Daniel Povinelli, biologist at the University of Louisiana, Lafayette, concludes, "Humans have a whole system that we call theory of mind that chimps don't have" (Povinelli, quoted in Pennisi 1999, 2076).

Some trans-genetic threshold seems to have been crossed. The human brain is of such complexity that descriptive numbers are astronomical and difficult to fathom. A typical estimate is $10^{12}$ neurons, each with several thousand synapses (possibly tens of thousands). Each neuron can "talk" to many others. The postsynaptic membrane contains over a thousand different proteins in the signal receiving surface. "The most molecularly complex structure known [in the human body] is the postsynaptic side of the synapse," according to Seth Grant, a neuroscientist at the University of Edinburgh (quoted in Pennisi 2006). Over a hundred of these proteins were co-opted from previous, non-neural uses; by far, the most of them evolved during brain evolution. This is nature's nanotechnology.

This nanophysiology is integrated into a dendritic network structured at multiple hierarchical levels. This network, formed and re-formed, makes possible virtually endless mental activity. Much, even most, of what goes on in our brains is below the level of conscious awareness, of course, but humans can bring to critical focus novel cognitive capacities. The result is a mental combinatorial explosion. The human brain is capable of forming thoughts numbering something in the range of $10^{70,000,000,000}$ thoughts-a number that dwarfs the number of atoms in the visible universe $\left(10^{80}\right)$ (Flanagan 1992, 37; Holderness 2001). On a cosmic scale, humans are minuscule atoms, but on a complexity scale, humans have "hyperimmense" possibilities in mental complexity (Scott 1995, 81). In our 150 pounds of protoplasm, in our three-pound brain is more operational organization than in the whole of the Andromeda galaxy.

Genes make the kind of human brains possible that facilitate an open mind. But when that happens, these processes can also work the other way around. What began as a "bottom-up" process becomes a "top-down" process. In "top down" causation, an emergent phenomenon re-shapes and controls its precedents, as contrasted with "bottom up" causation, in which precedent, simpler causes are fully determinative of more complex outcomes. Minds employ and reshape their brains to facilitate their chosen ideologies and lifestyles. Our ideas and our practices configure and re-configure our own sponsoring brain structures.

The linguistic ideational uniqueness involves complex use of symbols. Ian Tattersall, archaeologist at the American Museum of Natural History, New York, concludes, "We human beings are indeed mysterious animals. We are linked to the living world, but we are sharply distinguished by our cognitive powers, and much of our behavior is conditioned by abstract and symbolic concerns" (Tattersall 1998, 3). Similarly, Richard Potts, Smithsonian Institution's National Museum of Natural History, concludes, "All the odd elaborations of human life, socially and individually, including the heights of imagination, the depths of depravity, moral abstraction, and a sense of God, depend on this symbolic coding of the nonvisible (Potts 2004, 263). So humans alone produce both theory and practice, in science and mathematics, in ethics and politics, and in religious faith. 
Humans find themselves uniquely emplaced on a unique planet - in their world cognitively and critically as no other species is. Our bodily incarnation embeds us in this biospheric community; we are Earthlings. Our mental genius enables us to rise to transcending overview. So we can conclude that on this wonderland Earth, we Homo sapiens are the wonder of wonders. We can conclude that we are genius on top. Next, we have to wonder what that can mean-how can and ought we to be on top?

\section{Wondering about Anthropocene humans?}

By recent accounts, human dominance is so extensive that Earth has entered a new age, the Anthropocene epoch (Crutzen 2006a). The mental activity of humans reshaping their agentive capacities has in recent centuries produced technological development giving humans vast powers for transforming their planet through agriculture, industry, and technology. This has so dramatically escalated that we have entered the first century in the 45 million centuries of life on Earth in which one species can aspire to manage the planet's future.

What is the empirical evidence? Anthropocene enthusiasts say, "Just look, anywhere, everywhere. Human-dominated ecosystems cover more of Earth's land surface than do wild ecosystems" (McCloskey and Spalding 1989; Foley et al. 2005). Human agriculture, construction, and mining move more Earth than do the natural processes of rock uplift and erosion. Humans are now the most important geomorphic agent on the planet's surface (Wilkinson and McElroy 2007). "Human activities have become so pervasive and profound that they rival the great forces of Nature and are pushing the Earth into planetary terra incognita" (Steffen et al. 2007, 614). Geologists need stratigraphic evidence. The International Commission on Stratigraphy has a working group that has recommended Anthropocene as a geological unit (Waters et al. 2016).

Beyond the geology, "Anthropocene" has become an "elevator word" and put to use philosophically. The Economist has a cover story: "Welcome to the Anthropocene." "A Man-Made World." "The challenge of the Anthropocene is to use human ingenuity to set things up so that the planet can accomplish its 21 st century task." They foresee " 10 billion reasonably rich people" on a geoengineered, genetically synthetic Earth, re-built with humans in center focus (Economist 2011, 11, 81). Capitalist markets and the media feature increased fulfilling and expanding of human wants. The Anthropocene is "humanity's defining moment," according to the American Geosciences Institute (Seielstad 2012). "Humans are the ultimate ecosystem engineers" (Ellis and Ramankutty 2009). We are "the God species" (Lynas 2011).

Since Galileo, Earth seemed a minor planet, lost in the stars. Since Darwin, humans have come late and last on this lonely planet. Today, on our home planet at least, we are putting these once de-centered humans back at the center. We have entered the era of the imperial human domain. "What we call 'saving the Earth" will, in practice, require creating and re-creating it again and again for as long as humans inhabit it" (Shellenberger and Nordhaus 2011, 61). Humans are now 


\section{Holmes Rolston III}

"too big for nature." "Let us embrace the challenge to gain mastery over human engagement with the earth" (Ellis 2015). Enter the designer world.

This is illustrated in how human changes to the planet are producing global warming. Humans do not need ever again to face ice ages, as they did in the Pleistocene. Allen Thompson, an environmental philosopher, with a "radical hope for living well in a warmer world," urges us to find a significantly "diminished place for valuing naturalness," replacing it with a new kind of "environmental goodness ... distinct from nature's autonomy" (Thompson 2010, 43, 56). Erle Ellis, in what he calls the "Planet of No Return: Human Resilience on an Artificial Earth," celebrates "the beginning of a new geological epoch ripe with human-directed opportunity" (Ellis 2011, 44).

This is forcing humans to re-evaluate their role on the Earth in the future of their planet.

Yes, on Earth, humans are the wonder of wonders. But now we begin wonder about these Anthropocene humans-in a different sense of "wonder"--that of doubt and uncertainty, not of astonishment and marvel.

\section{Managed planet and end of nature?}

Enthusiasts for increasing human powers advocate that humans can and ought to manage their planet in their self-interest, engineering Earth resourcefully for increasing human benefits, bringing about the end of nature. Humans are now the most important geomorphic agent on the planet's surface. We should embrace the Anthropocene. We should use human ingenuity for an ever-escalating technology, ever-increasing human domination of the landscape, perpetual enlargement of the bounds of the human empire. In this mood, the Anthropocene enthusiasts are gung-ho for change.

The editors of a Scientific American special issue, Managing Planet Earth, ask, "What kind of planet do we want? What kind of planet can we get?" (Clark 1989). Find ways to redistribute rainfall, stop hurricanes and tsunamis, prevent earthquakes, redirect ocean currents, fertilize marine fisheries, manage sea-levels, alter landscapes for better food production, and generally make nature more userfriendly. Edward Yoxen urges,

The living world can now be viewed as a vast organic Lego kit inviting combination, hybridisation, and continual rebuilding. Life is manipulability. ... Thus our image of nature is coming more and more to emphasise human intervention through a process of design.

(Yoxen 1983, 15)

"The biosphere itself, at levels from the genetic to the landscape, is increasingly a human product (Allenby 2000, 11). We live in "anthropogenic biomes" (Ellis and Ramankutty 2008).

Geoengineering is "the intentional large-scale manipulation of the environment" (Keith 2000, 245). Paul Crutzen, the climate scientist who has dramatized 
the term "Anthropocene," argues that geoengineering "should be explored," given the dismal prospects of any other solution (Crutzen 2006b, 212). "The time has come to take it seriously. Geoengineering could provide a useful defense for the planet - an emergency shield that could be deployed if surprisingly nasty climatic shifts put vital ecosystems and billions of people at risk" (Victor et al. 2009, 66; Launder and Thompson 2010). There are several possibilities: Launch reflective particles into the upper atmosphere or aerosols or a cloud of thin refracting disks or reflective balloons, thereby cooling the Earth, as volcanic eruptions have done in the past. Or fertilize the ocean so as to increase plankton, which absorb more carbon. Or spray fine ocean water mist into the clouds to make them brighter, reflecting more sunlight. There are technological challenges to all these proposals. "Such schemes are fraught with uncertainties and potential negative effects" (Blackstock and Long 2010).

None of this sounds like humans intelligently re-engineering the planet on which they find themselves, rationally planning for an Anthropocene age. It sounds more like panic on a planet that the engineers are realizing that they have messed up, in ways they find almost beyond their control. Humans are smarter than ever, so smart that we are faced with overshoot (Dilworth 2010). Our power to make changes exceeds our power to predict the results, exceeds our power to control even those adverse results we may foresee.

There is concern about ending nature on Earth. "We live at the end of nature, the moment when the essential character of the world . . . is suddenly changing." Bill McKibben worries that already "we live in a postnatural world," in "a world that is of our own making." "There's no such thing as nature anymore" (McKibben 1989, 60, 85, 89, 175). There is only the built environment. Michael Soulé faces this prospect: "The term natural will disappear from our working vocabulary. The term is already meaningless in most parts of the world because anthropogenic [activities] have been changing the physical and biological environment for centuries, if not millennia" (Soule 1989, 301). We are at "the end of the wild" (Meyer 2006). We are "living through the end of nature" (Wapner 2010). Nature is over.

"Human beings are at the centre of concerns..." So the Rio Declaration begins, formulated at the United Nations Conference on Environment and Development and signed by almost every nation on Earth (UNCED 1992). This was once to be called the Earth Charter, but the developing nations were more interested in asserting their rights to develop and only secondarily in saving the Earth. The Rio claim is, in many respects, quite true. The human species is causing all the concern. The problem is to get people into "a healthy and productive life in harmony with nature" (UNCED 1992).

\section{Anthropocene arrogance}

Critics wonder about Anthropocene arrogance. A planet we manage, or attempt to manage, only to secure more and more profits and commodities for ourselves reveals an exploitive frame of mind. We shape our worldviews, and then our 


\section{Holmes Rolston III}

worldviews shape us. We fear that humans have become Earth's global consumer, Earth's juggernaut predator. The Anthropocene is colonialism resurrected in super global form. An overweening pride, hubris, is by many classical accounts the original human sin. "You shall be as gods" (Genesis 3 ).

What we must push for, according to the Royal Society of London, is "sustainable intensification" of reaping the benefits of exploiting the Earth (Royal Society 2009). Would not the world's oldest scientific society be as well advised to ask about protecting ancient and ongoing biodiversity, about how we might shrink our footprint, whether treading softly is wiser than ever intensifying our imperial exploitation? If we are to fix the problem in the right place, we must learn to manage ourselves as much as the planet.

David Biello, Scientific American's energy and environment editor, exclaims,

The stakes could not be higher. ... What we stand to gain is nothing less than an enduring civilization and a firmer understanding of our planet and ourselves. We have arrived at a new geologic epoch of our own making. . . . I argue the goal must be to make an enduring Anthropocene, an epoch that, in geologic and civilizational terms, stretches into an era.... This is not the end of the world. This is just the end of the world as we have known it.

(Biello 2016, 7-8)

Anthropocentric enthusiasts make the claim that such power is to be welcomed ethically. For all of human history, we have been pushing back limits. Especially in the West, we have lived with a deep-seated belief that life will get better, that one should hope for abundance and work toward obtaining it. Economists call such behavior "rational." Ethicists can agree: We ought to maximize human satisfactions, the abundant life, with more and more of the goods and services that people want. We have a right to self-development, to self-realization. Such growth, always desirable, is now increasingly possible.

Anthropocene enthusiasts may here deny arrogance. Just the other way around. They take the moral high ground: Classical conservation has been "socially unjust" (Kareiva and Marvier 2012, 965). "Protecting nature that is dynamic and resilient, that is in our midst rather than far away, and that sustains human communities these are the ways forward now. Otherwise, conservation will fail, clinging to its old myths." "Instead of pursuing the protection of biodiversity for biodiversity's sake, a new conservation should seek to enhance those natural systems that benefit the widest number of people, especially the poor" (Kareiva et al. 2011, 36-37).

The dream of living in harmony with nature is bygone. There is a more promising ambition: audacious humans manage their brave new world. Nature has been operating on the planet for five billion years. Human culture has been operating alongside and dependent on nature for something in the range of 40,000 to 100,000 years. Now the exuberant Anthropocene architects wish to displace globally systemic nature and radically shape the future as no generation before has had either the capacity or aspiration to do. And this will be a blessing in a more humane, equitable world. 
Critics worry that, though the intentions sound high, they have an immoral trailer. "Forward for me and my kind!" "Save nature for people, not from people." That could be as much the problem as the answer. The subtext seems to be the "old myths" that wildlife or ecosystems or biodiversity or evolutionary creative genesis have goods of their own, intrinsic value worth protecting. Essentially this puts us as the first, if not the only, location of moral relevance. Justice is justus. This is the Anthropocene, and too bad for the non-anthropic. Anthropocene proponents are concerned to get people fed, even if doing so drives tigers and butterflies into extinction.

Kareiva and Marvier urge us to shift "from a focus almost exclusively on biodiversity" to more attention to

human well-being. ... Conservation is fundamentally an expression of human values... . Today we need a more integrative approach in which the centrality of humans is recognized. ... We do not wish to undermine the ethical motivations for conservation action. We argue that nature also merits conservation for very practical and more self-centered reasons concerning what nature and healthy ecosystems provide to humanity.

(Kareiva and Marvier 2012, 963-65)

Despite the caveat, ethical concern for non-humans is soon undermined. We may be told that once-abundant species can vanish with no ill effects on humansthe bison, the chestnut, the passenger pigeon, the dodo, the tigers and butterflies. Putting ourselves first makes it difficult to appreciate the other-than-human.

Rebuilding the planet with humans at the center, or even protecting ecosystem services so long as these benefit us, no longer sounds like the high moral ground. Nature is of value only if and so far as it supports human enterprises. This puts the whole planet in the service of only one species - an unnatural condition. If our concern is for the poor in this new humanist excellence, then why not emphasize environmental justice, more equitable distribution of wealth between rich and poor on developed lands, rather than diminishing wild nature to benefit the poor?

On future Earth, it is hard to imagine a world without ongoing developmentwithout engines and gears, without electricity, without cars, cell phones, computers. We expect ever-escalating high technology in our service. Self-fulfilling desires intoxicate us; we grow addicted to them. In the Anthropocene, we might indeed get more and more of what we want. But this might lead us to accept an environment increasingly toxic and degraded by global warming. This might lead our children not to notice their hotter, less diverse, less stable environment. We, our children, our children's children will never know our highest flourishing, dumbed down by our ever more assertive self-interests. "Quite possibly, then, this era, which so congratulates itself on its self-awareness, will come to be known as the time of the Great Derangement" (Ghosh 2016, 11).

Here is what Anthropocene proponents need first to confront. A massive Millennium Ecosystem Assessment, sponsored by the United Nations, involving over 1,300 experts from almost 100 nations, begins, "At the heart of this assessment 


\section{Holmes Rolston III}

is a stark warning. Human activity is putting such strain on the natural functions of Earth that the ability of the planet's ecosystems to sustain future generations can no longer be taken for granted" (Millennium Ecosystem Assessment 2005, 5). Encouraging a new Anthropocene epoch with ever-increasing human desires seems a deranged policy, far more likely to increase this strain than to reduce it. Anthropocene managers are unlikely to address harmful results, possible or probable, distant from themselves in time and space.

The geoengineers will find that their engineering is not just a technical problem; they have to consider the social contexts in which they launch their gigantic projects, the welfare and risks of those they seek to save, the (in)justice of geoengineering that spreads benefits and costs inequitably, the governance of geoengineering (Parson and Keith 2013). Engineers are no better equipped to deal with transdisciplinary systems problems than are the politicians. Or with the ethical problems. They may find a majority of Earth's residents wondering, Is our only relationship to nature one of engineering it for the better?

Now Allen Thompson, joined by Jeremy Bendik-Keymer, backs off, more inclined to work with, rather than revise, the basic processes in ecosystems. "Far from the current rush toward geoengineering, this kind of response would exhibit the virtue of humility" (Thompson and Bendik-Keymer 2012, 15). David Biello too worries about reckless Anthropocene over-management. "This is about managing change, adapting to it, and increasing the resilience of our civilization at the same time as we make more room for our fellow travelers on this life bearing spaceship" (Biello 2016, 7). We do not want Earth transformed into an artifact.

Several billion years' worth of creative toil, several million species of teeming life, have been handed over to the care of this late-coming species in which mind has flowered and morals have emerged. Ought not those of this sole moral species do something less self-interested than count all the produce of an evolutionary ecosystem resources to be valued and re-engineered only for the benefits they bring? Such an attitude hardly seems biologically informed, much less ethically adequate. Its logic is too provincial for moral humanity.

\section{Wonderful humans incarnate on wonderland Earth}

Humans coinhabit Earth with five to ten million other species, and we and they depend on surrounding biotic communities. There are multiple dimensions of naturalness, on both public and private lands. George Peterken, British ecologist, has an eight-point scale (Peterken 1996). Even on long-settled landscapes, there can be natural woodlands, treasured by owners over centuries. There may be native woodlands, often with quite old trees, secondary woodlands with trees fifty to a hundred years old, recently restored woodlands, wetlands, moors, hedgerows, mountains, such as the Alps or the Scottish Cairngorms. Gregory Aplet, a US forest ecologist, distinguishes 12 landscape zones, placed on axes of human "controlled" to autonomously "self-willed" and "pristine" to "novel." Rather than seeking to press onward toward totally managed Earth, why not claim that there are and ought to be various degrees of the preservation-conservation-Anthropocene spectrum? 
Zoning the landscape, how much human management do we apply where? Which are urban lands? Which are working landscapes, rural or dedicated to multiple use? This "right-sizing" policy question seems to demand a more specific answer than we actually need to give, if we are concerned with sizing the human presence on future Earth. Wilderness is the most endangered landscape, the least-sized, the one in shortest supply. Save all you can. Right-size agricultural landscapes not by re-engineering weather, climate, and soil geologies but by right-sizing human populations at levels suitable as adapted fits in their supporting rural communities with ecosystem services. Technology can overcome some constraints (fossil fuels, nitrogen fertilizers) but only within ecosystem constraints (global warming, nitrogen-polluted waters). Right-size cities by keeping them sustainable on their supporting agricultures and ecosystems. Right-size humans by keeping them at home on their planet.

Rocket scientists, loving their marvelous, high-tech machines, are still concerned to celebrate our organic, vital planet. Viewing Earthrise from the moon, the astronaut Edgar Mitchell was entranced:

Suddenly from behind the rim of the moon, in long, slow-motion moments of immense majesty, there emerges a sparkling blue and white jewel, a light, delicate sky-blue sphere laced with slowly swirling veils of white, rising gradually like a small pearl in a thick sea of black mystery. It takes more than a moment to fully realize this is Earth ... home.

(Mitchell, quoted in Kelley 1988, at photographs 42-45)

Humans are most wonderful, full of wonder, wonder-full when caring for this small, immensely majestic, precious pearl in the mystery of deep space. We do not want a de-natured life on a de-natured planet.

Our best hope is for a tapestry of cultural and natural values, not a trajectory even further into the Anthropocene. Keep nature in symbiosis with humans. Keep the urban, rural, and wild. Our future ought to be the Semi-Anthropocene, kept basically natural - with the natural basics - and entered carefully - full of cares for both humans and nature on this marvelous home planet. Cherish wonderful humans incarnate on wonderland Earth.

\section{References}

Allenby, B. "Earth Systems and Engineering and Management." IEEE Technology and Society Magazine 19, no. 4 (2000): 10-24.

Aplet, Gregory H. "On the Nature of Wildness: Exploring What Wilderness Really Protects." University of Denver Law Review 76 (1999): 347-67.

Barrow, John D. The Constants of Nature. New York: Pantheon Books, 2002.

Biello, David. The Unnatural World: The Race to Remake Civilization in Earth's Newest Age. New York: Simon and Schuster, Scribner, 2016.

Blackstock, J. J. and J. C. S. Long. "The Politics of Geoengineering." Science 327 (January 29, 2010): 527. 


\section{Holmes Rolston III}

Clark, W. C. "Managing Planet Earth." Scientific American 261, no. 3 (September 1989): $46-54$.

Collins, Michael. "Foreword." In Our Universe, edited by Roy A. Gallant. Washington, DC: National Geographic Society, 1980.

Crutzen, Paul J. "Albedo Enhancement by Stratospheric Sulfur Injections: A Contribution to Resolve a Policy Dilemma?" Climatic Change 77 (2006): 211-19.

Crutzen, Paul J. "The 'Anthropocene'." In Earth System Science in the Anthropocene, edited by Eckart Ehlers and Thomas Kraft, 13-18. Berlin: Springer, 2006.

Davies, Paul. Cosmic Jackpot: Why Our Universe Is Just Right for Life. Boston: Houghton Mifflin, 2007.

Dilworth, Craig. Too Smart for Our Own Good: The Ecological Predicament of Humankind. Cambridge: Cambridge University Press, 2010.

Dorus, Steve, et al. "Accelerated Evolution of Nervous System Genes in the Origin of Homo sapiens." Cell 119 (2004): 1027-40.

The Economist. "Welcome to the Anthropocene." 399, no. 8735 (2011).

Ellis, Erle. "The Planet of No Return." Breakthrough Journal 2 (Fall 2011): 39-44. http:// thebreakthrough.org/index.php/journal/past-issues/issue-2/the-planet-of-no-return.

Ellis, Erle. "Too Big for Nature." In After Preservation: Saving American Nature in the Age of Humans, edited by Ben A. Minteer and Stephen J. Pyne, 24-31. Chicago: University of Chicago Press, 2015.

Ellis, Erle and Navin Ramankutty. "Anthropogenic Biomes." Encyclopedia of Earth. 2009. http://ecotope.org/people/ellis/papers/ellis_eoe_anthromes 2007.pdf.

Ellis, Erle and Navin Ramankutty. "Putting People in the Map: Anthropogenic Biomes of the World." Frontiers in Ecology and the Environment 6, no. 8 (2008): 439-47.

Flanagan, Owen. Consciousness Reconsidered. Cambridge, MA: MIT Press, 1992.

Foley, Jonathan A., Ruth DeFries, Gregory P. Asner, et al. "Global Consequences of Land Use." Science 309 (July 22, 2005): 570-74.

Gazzaniga, Michael S. Human: The Science Behind What Makes Us Unique. New York: Ecco, Harper Collins, 2008.

Ghosh, Amitav. The Great Derangement: Climate Change and the Unthinkable. Chicago: University of Chicago Press, 2016.

Holderness, Mike. "Think of a Number." New Scientist 170 (June 16, 2001): 45.

Kareiva, P., R. Lalasz, and M. Marvier. "Conservation in the Anthropocene. Beyond Solitude and Fragility." Breakthrough Journal 2 (Fall 2011): 29-37.

Kareiva, P. and M. Marvier. "What Is Conservation Science?" BioScience 62 (2012): 962-69.

Keith, D.W. "Geoengineering the Climate: History and Prospect." Annual Review of Energy and the Environment 25 (2000): 245-84.

Kelley, Kevin W., ed. The Home Planet. Reading, MA: Addison-Wesley, 1988.

Launder, B. and J. Thompson. Geoengineering Climate Change: Environmental Necessity or Pandora's Box? Cambridge: Cambridge University Press, 2010.

Lynas, Mark. The God Species: Saving the Planet in the Age of Humans. Washington, DC: National Geographic, 2011.

McCloskey, J. M. and H. Spalding. "A Reconnaissance Level Inventory of the Amount of Wilderness Remaining in the World." Ambio 18 (1989): 221-27.

McKibben, Bill. The End of Nature. New York: Random House, 1989.

Meyer, Stephen M. The End of the Wild. Cambridge, MA: The MIT Press, 2006.

Millennium Ecosystem Assessment. Living Beyond Our Means: Natural Assets and Human Well-Being: Statement from the Board. Washington, DC: World Resources Institute, 2005. 
Parson, E. A. and David W. Keith. "End the Deadlock on Governance of Geoengineering Research." Science 339 (2013): 1278-79.

Pennisi, Elizabeth. "Are Our Primate Cousins 'Conscious'?" Science 284 (1999): 2073-76.

Pennisi, Elizabeth. "Brain Evolution on the Far Side." Science 314 (October 13, 2006): 244-45.

Penrose, Roger. The Road to Reality: A Complete Guide to the Laws of the Universe. New York: Alfred A. Knopf, 2005.

Peterken, George F. Natural Woodland: Ecology and Conservation in Northern Temperate Regions. Cambridge: Cambridge University Press, 1996.

Potts, Richard. "Sociality and the Concept of Culture in Human Origins." In The Origins and Nature of Sociality, edited by Robert W. Sussman and Audrey R. Chapman, 249-69. New York: Aldine de Gruyter, 2004.

Rees, Martin. Just Six Numbers: The Deep Forces That Shape the Universe. New York: Basic Books, 2000.

Royal Society of London. Reaping the Benefits: Science and the Sustainable Intensifcation of Global Agriculture. London: Royal Society, 2009. http://royalsociety.org/ Reapingthebenefits/.

Scott, Alwyn. Stairway to the Mind: The Controversial New Science of Consciousness. New York: Copernicus; Springer-Verlag, 1995.

Seielstad, George A. Dawn of the Anthropocene: Humanity's Defining Moment. Alexandria, VA: American Geosciences Institute, 2012. (A digital book)

Shellenberger, M. and T. Nordhaus. "Evolve: A Case for Modernization as the Road to Salvation." Orion 30, no. 1 (September/October 2011): 60-65.

Sophocles. Antigone. 1900. R. C. Jebb, Sophocles: Plays. Antigone (facsimile reprint: London: Bristol Classical Press, 2004), line 325, p. 60.

Soulé, Michael E. "Conservation Biology in the Twenty-first Century: Summary and Outlook." In Conservation for the Twenty-First Century, edited by David Western and Mary Pearl. Oxford: Oxford University Press, 1989.

Steffen, Will, Paul J. Crutzen, and John R. Mitchell. "The Anthropocene: Are Humans Now Overwhelming the Great Forces of Nature?" Ambio 26, no. 2 (2007): 614-21.

Tattersall, Ian. Becoming Human: Evolution and Human Uniqueness. New York: Harcourt Brace, 1998.

Tegmark, Max. "Is the Theory of Everything Merely the Ultimate Ensemble Theory?" Annals of Physics 270 (1998): 1-51.

Thomas, Lewis. The Lives of a Cell. New York: The Viking Press, 1975.

Thompson, A. "Radical Hope for Living Well in a Warmer World." Journal of Agricultural and Environmental Ethics 23 (2010): 43-59.

Thompson, A. and J. Bendik-Keymer, eds. Ethical Adaptation to Climate Change: Human Virtues of the Future. Cambridge, MA: The MIT Press, 2012.

Tomasello, Michael, Ann Cale Kruger, and Hilary Horn Ratner. "Cultural Learning." Behavioral and Brain Sciences 16, no. 3 (1993): 495-552.

United Nations Conference on Environment and Development (UNCED). The Rio Declaration. 1992. www.unesco.org/education/pdf/RIO_E.PDF.

Venter, J. Craig, et al. "The Sequence of the Human Genome." Science 291 (February 16, 2001): 1304-51.

Victor, D. G., M. G. Morgan, J. Apt, J. Steinbumer, and K. Ricke. "The Geoengineering Option: A Last Resort Against Global Warming?" Foreign Affairs 88, no. 2 (March/ April 2009): 64-76.

Wapner Paul. Living Through the End of Nature: The Future of American Environmentalism. Cambridge, MA: MIT Press, 2010. 


\section{Holmes Rolston III}

Ward, Peter D. and Donald Brownlee. Rare Earth: Why Complex Life Is Uncommon in the Universe. New York: Copernicus; Springer-Verlag, 2000.

Waters, Colin N., et al. "The Anthropocene Is Functionally and Stratigraphically Distinct from the Holocene." Science 351 (2016): 137. http://dx.doi.org/10.1126/science. aad2622.

Wilkinson Bruce H. and Brandon J. McElroy. "The Impact of Humans on Continental Erosion and Sedimentation." Geological Society of America Bulletin 119 (2007): 140-56.

Wilson, Edward O. On Human Nature. Cambridge, MA: Harvard University Press, 1978.

Yoxen, E. The Gene Business: Who Should Control Biotechnology? New York: Harper and Row, 1983. 